\title{
Factors Affecting Consumer Purchase Intention of Smartphones: A Case of Hawassa City
}

\author{
Amanuel Engidaw \\ Lecturer, College of Business and Economics, Department of Marketing Management, Mekdela Amba \\ University, P.O.Box: 32, Mekane Selam, Ethiopia
}

\begin{abstract}
The growing need and fast development of technology in the era of globalization, free markets, and more fierce competition made the company produce products to satisfy the diverse needs of customers, particularly within the smartphone industries. The major objective of this study was to assess factors affecting consumers' purchase intention of smartphones; a case of Hawassa city. A structured schedule that has three sections was used to collect the primary data. A complete sample of 385 consumers selected by employing the population precision method. The enumerator administered schedule is distributed to all the selected consumers. The research used a systematic random sampling technique at the time of data collection. However, only 356 consumers responded genuinely, and hence, the response rate was 92.46 percent. Descriptive and inferential statistical tools such as; frequency tables, percentages, means, standard deviations, Pearson correlation, and multiple regression analysis were used to data analysis. The result of the adjusted $\mathrm{R}$ square is 0.645 , which demonstrates that 64.5 percent of purchase intention variation can be explained by the independent variables. Based on the statistical analyses, all variables namely price, product feature, brand name, advertising, and social influence have a positive relationship with the consumers' purchase intention. The researcher has drawn the following recommendations. Smartphone manufacturers and marketers should carry out a periodic survey to help in identifying new features and decide which ones to add to its product, follow a value-based pricing strategy, strive to create positive word of mouth among consumers, advertising messages should be designed in a manner that is clear, understandable and not offensive to the consumers and build their strong brand name; establish the link of their brand name with the consumers through unique sources of communication.
\end{abstract}

Keywords: Purchase Intention, Smart Phone, Hawassa city

DOI: $10.7176 / \mathrm{EJBM} / 12-25-03$

Publication date:September $30^{\text {th }} 2020$

\section{INTRODUCTION}

The exponential growth of cell phone technologies has created additional affordances and new channels of communicating and presenting the information. The capability and performance of cell phones have improved considerably since their first introduction, and are no longer simple voice-centric devices. We can understand that smartphones are the advanced form of mobile phones which provides a wide range of application to the consumer such as the advance ability of computing, it also provides all things which a computer system provides as well as access the internet on high speeds can be possible (Gupta \& Sheoran, 2013). Supporting this, (Sabnam, 2016) stated that, in today's modern life, it plays a predominant role since mobile phones these days are used by people at all levels across the world. Handset manufacturing organizations in present times are eager to know what factors influence the buying behavior of an individual (Ibid, 2016). At this time smartphones are at the heart of many individuals because of convincing for handling, regardless of their sizes having many applications, easy to access the latest cyber sources, and for their multiple functions.

Similarly, Kaushal and Rakesh (2016) explained that with a smartphone one can not only just call and send messages to other but also can use the internet easily and can connect on social media portals like Facebook, Twitter, WhatsApp, Viber, etc. along with audio-video facility and instant messaging. These features draw a demarcating line between ordinary mobile phones and smartphones and make the use of smartphones more easy and user-friendly and increase its utility for the consumers.

According to (Nagarkoti, 2009), the rapidly growing demand for smartphones has created a buzz around the world. Nowadays, most consumers opt to have a smartphone. Smartphones are configured by an operating system with advanced computing capability and connectivity. Most people use applications for internet browsing, email, social media, listening to music, reading news, games, finance, health, and fitness, taking notes, calendar, weather forecasts, and lots of other things. These features and applications in smartphones somehow have made people's life easier either in daily life, at work, or for entertainment purposes.

Smartphones are explicitly distinguished from standard mobile phones in terms of their operating system and their purpose of use such as social networking, reading e-books, replying e-mails, browsing information, shopping, entertainment, and other featured functions (Liu \& Liang, 2014; Wang et al., 2015 cited in Ali et al., 2015). Above all, the recent developments of advanced operating systems, numerous applications, and competition in the telecommunication market have led to a significant increase in the number of smartphone users (Park et al., 2013). 
According to the latest forecasts (Statista, 2015), the number of smartphone users worldwide is expected to be almost 2.16 and 2.56 billion people in 2016 and 2018, respectively. Another most recent smartphone shipment forecast (International Data Corporation, 2015) exhibits that smartphone shipments are expected to grow $10.4 \%$ in 2015, while Android has the largest market share with an expected $81.1 \%$ market share in terms of operating systems. This rapid adoption of smartphones and the overwhelming development of mobile applications have been changing the consumer's behavior for the interaction of a smartphone brand (Kim et al., 2015).

Ayodele et al. (2016) argued that smartphone usage is still at the introductory stage in Africa with just $2 \%$ market size in comparison to China with 27\%, Europe with 17\%, emerging Asia with 14\%, and North American and Latin American with 13\% and 14\% respectively. According to the Pew Research Center report (2016), South Korea stands out as the country with the highest smartphone ownership rate, with $88 \%$ of respondents saying they own one. In contrast, Tanzania (11\%), Uganda (4\%), and Ethiopia (4\%) are among the poorest countries with the least smartphone ownership rates.

Thus, this low rate of smartphone penetration in the poorest countries shows that they are not using smartphones like other developed countries. In this circumstance, the reason for the low penetration rate of the smartphone needs research, particularly in Ethiopia. By taking into consideration this issue, the researcher was motivated to conduct this research on factors affecting an individual's purchasing intention towards smartphones in Hawassa city.

\subsection{Statement of the Problem}

Now, here we are living in a highly developed and technologically advanced era. Individuals have plenty of choices and options to decide on their needs. In this regard, smartphone manufacturers, discover consumers' preferences, and predicting consumer behavior is the key to conquer the smartphone market. Though many companies can have better products and yet are sometimes unable to compete in the market due to various factors affecting their product marketing.

Several studies are conducted to identify factors affecting consumers' choice of smartphones. These studies indicated a range of items as a determinant factor influencing purchasing intention. Chew et al. (2012) researched to identify influencing factors affecting the purchase intention of smartphones and concluded as social influence, price and compatibility were significant positive influences on the purchase intention while the only relative advantage is having less impact on the dependent variable. Surendra et al. (2013) also conducted a study on factors influencing consumer's purchase decision towards smartphones in Indore, identifies the key factors which have a dominating effect on the consumers' minds while purchasing smartphones. The result showed that four factors price, brand, social influence, and features having a dominant influence on the purchase decision of consumers in Indore.

In Ethiopia, it is becoming common to see people with their touch screen smartphones almost everywhere. Mobile phone retailers located in different corners of the country also validate the emergence of the smartphone market. Individuals own various brands of smartphone based on their choice. The reason behind the diverse kinds of preferences is due to the factors that determine the consumers' purchase behavior of smartphone and their inclinations.

According to the preliminary study conducted in the study area, consumers are willing to buy a wellrecognized brand at a high price even though many smartphones perform almost the same operation comparatively with the cheapest price. Besides, they consider other factors related to their purchase decision like seeking advice from parents and friends, visit different smartphone shops for comparison of brands and product features. By understanding customer intentions smartphone companies are improving the technology dramatically. But the battery technology in smartphones is not that much improving at the same pace, some smartphones do not support the sharing of data with other smartphone holders, highly-priced (i.e., iPhone, Samsung), and most of the time consumers hesitate to purchase smartphone due to the existence of high copied products.

To predict consumer behavior, marketers are using purchase intention as a predictor of future behavior. It is an important issue to recognize and evaluate the factors affecting consumers' smartphone purchase intention. Therefore, this article intended to assess factors that determine consumers' purchasing intentions towards the smartphone in Hawassa city.

\subsection{Objectives of the Study}

The general aim of this research is to assess factors affecting consumers' purchase intention of smartphones in Hawassa city. The specific objectives of the study include:

\# To assess the influence of price on consumers' purchase intention of smartphones

* To identify the relationship between the product feature and consumers' purchase intention

* To assess the impact of a brand name on consumers' smartphones purchase intention

* To assess the effect of advertising on consumers' purchase intention of smartphones

$\$$ To identify whether social influence has a significant effect on consumers' smartphone purchase intention 


\section{Materials and Methods}

The study employed both qualitative and quantitative research approaches. Creswell (2003) discusses that the mixed method approach is a model for social research combining qualitative and quantitative methodologies that is adequately flexible, accessible, and multilayered to interpret real meaning from the collected data. The researcher has also employed a mixed method of descriptive and explanatory research design for the study. Of the several techniques used to collect relevant data, a survey was chosen as the most appropriate technique to collect data.

Data were collected by using a schedule administered to a sample; these data are standardized, allowing easy comparison. The research design was cross-sectional when we see in the time aspect. To achieve the research objectives and the reliability of data, both qualitative and quantitative data were collected from both primary and secondary data sources. Primary data were collected from smartphone consumers through enumerator administered schedules; which comprises both open-ended and close-ended questions. Secondary data were collected from different journals, and publications for assessing the existing findings, internet, books, and documents.

The researcher considers all smartphone consumers found in Hawassa city as a study population. However, since the number of smartphone consumers is unknown and infinite, it is difficult to provide the appropriate figure of the population of the study. To get these consumers, the researcher adopted Mesay (2013) technique; mobile shops were selected as a suitable place for this study. Mobile shops located around Menaharia (Ermi Mobile and Electronics Center), Piazza (John Mobile Center), and Sefere Selam (Lidet General Trading) were taken to approach respondents. Therefore, the accessible population of the study was consumers those involved in purchasing a smartphone as well as appearing on those smartphone shops for purchasing other electronic products who have a smartphone. After identifying the target population, the researcher decided to split the sample proportion for the three selected shops found in different areas. After this, the researcher employed systematic random sampling.

The representative number of samples has been specified by using the Cochran (1977) sample size determination formula:

$\mathrm{n}=\left(\frac{\mathrm{z}}{\mathrm{e}}\right)^{2} \mathrm{pq}=\left(\frac{1.96}{0.05}\right)^{2}(0.5)(0.5)=384.16 \approx 385$

Where, $\mathrm{n}=$ sample size to be calculated

$\mathrm{p}=$ Percentage or presence of the study characteristics ( $p=0.5$, maximum variability), when it is not known a conservative value of $\mathrm{P}=0.5$ is assumed

$\mathrm{q}=1-\mathrm{p}$

$\mathrm{e}=$ accepted margin of error $( \pm 5 \%$ of precision $)$

$z=1.96(95 \%$ of confidence level)

Therefore, the representative number of respondents (smartphone consumers) is 385 .

Both primary and secondary data were collected from relevant sources that help to achieve the stated objectives. Primary data were collected from individual smartphone users at mobile shops in the selected areas through the enumerator administered schedule. The questions have been adapted from the work of Chew et al. (2012); Lim (2014); Amrit (2014); Tanzila et al. (2015) and Mesay (2013).

The schedule was prepared in 5 points Likert's scale from (1) strongly disagree to (5) strongly agree and tested on 15 respondents to assess the reliability or internal consistency. The pilot test was conducted by the Alpha (Cronbach) model. After checking each item in the schedule, the researcher made some modifications.

The data collected from the respondents were processed; the data was first checked/edited to ensure completeness, accuracy, and uniformity. All instruments were assigned serial numbers to facilitate identification and data entry into the computer. The data was coded after checking/editing and entered into the computer for analysis.

As for this research, all the important and relevant data were collected and eventually use a computer program to analyze the data in depth. Most of the computer analysis was being conducted by using Statistical Packaging for Social Science (SPSS) version 20. To meet the specified research objectives, both descriptive and inferential statistical techniques have been adopted to analyze the data.

\section{RESULTS AND DISCUSSION}

To achieve the objective of the research, the researcher had distributed 385 copies of schedules (enumerator administered questionnaires) to respondents. But, 356 respondents completed the schedule genuinely. From this, we can understand that the response rate is $92.46 \%$. The remaining 29 schedules were fault replied, blank, and missing by respondents. The data collected were entered into SPSS version 20, and various statistical steps were applied to arrive at the desired output for analysis and presentation. The analysis part was made using both descriptive and inferential statistics. 


\subsection{Descriptive Analysis}

\subsubsection{Demographic Profile of Respondents}

Demographic information provides insight understanding of the characteristics of the respondents who were sampled during the study. This was considered to be necessary because it assists the researcher to understand the targeted group in detail. Therefore, the demographic variables of this thesis for discussion were gender, age, education level, occupation, and monthly income.

Table 1: Demographic Background of Respondents

\begin{tabular}{|c|c|c|c|c|c|}
\hline No. & $\begin{array}{l}\text { Type of } \\
\text { Variables }\end{array}$ & Category & Frequency $(n=356)$ & Percentage & $\begin{array}{l}\text { Cumulative } \\
\text { Percentage }\end{array}$ \\
\hline \multirow[t]{2}{*}{1} & \multirow[t]{2}{*}{ Gender } & Male & 211 & 59.3 & 59.3 \\
\hline & & Female & 145 & 40.7 & 100.0 \\
\hline \multirow[t]{5}{*}{2} & \multirow[t]{5}{*}{ Age } & Below 18 & 10 & 2.8 & 2.8 \\
\hline & & $18-28$ & 212 & 59.6 & 62.4 \\
\hline & & $29-38$ & 101 & 28.4 & 90.7 \\
\hline & & $39-48$ & 26 & 7.3 & 98.0 \\
\hline & & above 48 & 7 & 2.0 & 100.0 \\
\hline \multirow[t]{7}{*}{3} & \multirow{7}{*}{$\begin{array}{l}\text { Level of } \\
\text { Education }\end{array}$} & Illiterate & 0.0 & 0.0 & 0.0 \\
\hline & & Non-Formal Education & 3 & 0.8 & 0.8 \\
\hline & & Below Grade 8 & 20 & 5.6 & 6.5 \\
\hline & & Grade $8-12$ & 65 & 18.3 & 24.7 \\
\hline & & Certificate and diploma & 58 & 16.3 & 41.0 \\
\hline & & Bachelor Degree & 164 & 46.1 & 87.1 \\
\hline & & $2^{\text {nd }}$ Degree and above & 46 & 12.9 & 100.0 \\
\hline \multirow[t]{5}{*}{4} & \multirow[t]{5}{*}{ Occupation } & Government Employee & 143 & 37.6 & 37.6 \\
\hline & & Self-employed & 98 & 27.5 & 65.2 \\
\hline & & Student & 87 & 24.4 & 89.6 \\
\hline & & Unemployed & 23 & 6.5 & 96.1 \\
\hline & & NGO Employee & 14 & 3.9 & 100.0 \\
\hline \multirow[t]{5}{*}{5} & \multirow{5}{*}{$\begin{array}{l}\text { Income per } \\
\text { Month }\end{array}$} & Below 2000 & 40 & 11.2 & 11.2 \\
\hline & & $2000-4000$ & 98 & 27.5 & 38.8 \\
\hline & & $4100-6100$ & 88 & 24.7 & 63.5 \\
\hline & & $6200-8200$ & 105 & 29.5 & 93.0 \\
\hline & & Above 8200 & 25 & 7.0 & 100.0 \\
\hline
\end{tabular}

Source: Own Survey Questionnaire, 2017

As Table 1 shows, the result of gender analysis consists of 211 males and 145 females. The percentage of males is $59.3 \%$, whereas females are $40.7 \%$, a difference of $18.6 \%$. This implies that male smartphone users were slightly higher than females.

Concerning age, the majority of the respondents were in the age range of 18-28 years old which consists of $59.6 \%$. Followed by $29-38$ years, this constitutes 101 (28.4\%). Respondents between the age of 39-48 ranked third, which contains $26(7.3 \%)$ while $10(2.8 \%)$ are with the age category of below 18 , and those in the category of above 48 years account the least amount $7(2.0 \%)$. Thus, $313(88 \%)$ of the respondents are within the age range of 18-38. From this, we can understand that smartphones are more preferred and used by the young generation.

Referring to education level, $164(46.1 \%)$ of respondents which are bachelor degree, and followed by $65(18.3 \%), 58(16.3 \%)$, and $46(12.9 \%)$ with the level of education grade $8-12$, certificate and diploma, and $2^{\text {nd }}$ degree and above respectively. Respondents that have less in number were below grade 8 which consists of $20(5.6 \%)$ and non-formal education 3(0.8\%). There were no respondents under the category of "illiterate". From this, we can understand that large numbers of smartphone consumers were individuals categorized under a bachelor's degree level of education. Smartphones by their nature have a sophisticated operating system and user interface, to communicate gently the educational status of the consumer determines their intention to purchase.

Regarding the occupation, Government employees constituted the large scale, which was $134(37.6 \%)$ followed by self-employed/businessmen 98 (27.5\%), students 87 (24.4\%), unemployed 23 (6.5\%), and 14 (3.9\%) for those who work under NGO. Then, it is possible to say that the majority of smartphone consumers are working in government sectors and businessmen category. Therefore, the number of smartphone users varies in different occupation categories.

As can be seen again from table 1 above, a large number of respondents, 105 (29.5\%) of respondents who were the biggest group to getting income between 6,200-8,200 birr per month, followed by 98 (27.5\%) of respondents of income among 2,000-4,000 birr per month. 88 (24.7\%) of respondents got income among 4,1006,100 birr per month, $40(11.2 \%)$ of respondents got income below 2000.00 and the last group got the income 
more than 8,200 birrs per month were $25(7.0 \%)$ of respondents. The income factor under this paper implies that most of the smartphone consumers are within the income category of 2,000-8,200 birr per month. Therefore, consumer economic condition influences his/her purchasing intention towards a smartphone. If the income and savings of a consumer are high, then he/she will purchase a more expensive smartphone. On the other hand, a person with low income and savings will purchase an inexpensive product like a feature phone.

\subsubsection{Information about the Use of Smart Phone}

\section{Do you own a smart phone?}

Respondents were asked to respond on whether they have a smartphone. A total of 356 respondents have participated in the survey. Since this research study considers only real consumers of a smartphone, therefore no non-smartphone consumer/there may be potential consumer/ respondents are made involved in this survey. Based on the result, all respondents are smartphone consumers which represent $100 \%$ of the total respondents.

\section{Which brand of smart phone you are currently using?}

Table 2: Brand of Smart Phone Respondents Currently Using

\begin{tabular}{|l|l|l|l|l|l|}
\hline & Smartphone brand name & Frequency & Percent & Valid Percent & Cumulative Percent \\
\hline Valid & Samsung & 87 & 24.4 & 24.4 & 24.4 \\
\cline { 2 - 6 } & Huawei & 131 & 36.8 & 36.8 & 61.2 \\
\cline { 2 - 5 } & Tecno & 59 & 16.6 & 16.6 & 77.8 \\
\cline { 2 - 5 } & LG & 7 & 2.0 & 2.0 & 79.8 \\
\cline { 2 - 5 } & Infinex & 21 & 5.9 & 5.9 & 85.7 \\
\cline { 2 - 6 } & Itel & 28 & 7.9 & 7.9 & 93.5 \\
\cline { 2 - 6 } & Sony & 7 & 2.0 & 2.0 & 95.5 \\
\cline { 2 - 6 } & Blackberry & 0.0 & 0.0 & 0.0 & 95.5 \\
\cline { 2 - 5 } & Asus & 3 & 0.8 & 0.8 & 96.3 \\
\cline { 2 - 5 } & IPhone & 8 & 2.2 & 2.2 & 98.6 \\
\cline { 2 - 5 } & Nokia & 0.0 & 0.0 & 0.0 & 98.6 \\
\cline { 2 - 5 } & HTC & 2 & 0.6 & 0.6 & 99.2 \\
\cline { 2 - 5 } & Others & 3 & 0.8 & 0.8 & 100.0 \\
\cline { 2 - 5 } & Total & 365 & 100.0 & 100.0 & \\
\hline
\end{tabular}

Source: Own Survey Questionnaire, 2017

As in Table 2 shown, twelve different smartphone brands were used by consumers at large. The Smartphone brands include; Samsung, Huawei, Tecno, LG, Infinix, Itel, Sony, Blackberry, Asus, iPhone, Nokia, HTC. According to the result obtained, the majority of the smartphone users were using the Huawei brand. There were $131(36.8 \%)$ of the respondents using Huawei as their current smartphone. The second smartphone brand that most of the respondents were using is Samsung which has 87 frequencies that stand $24.4 \%$ of the total respondents. Next, the third-highest brand that is owned by most of the respondents is Tecno with 59 frequencies that stand 16.6 percent followed by itel 28 (7.9\%), Infinex 21 (5.9\%), iPhone 8 (2.2\%), and LG and Sony both have $7(2.0 \%)$. Asus and HTC have the least frequencies among the other brands. Both of these brands have only $3(0.8 \%)$ and 2 $(0.6 \%)$ respectively. No respondent uses two smartphone brands provided/listed i.e. Nokia and Blackberry. For respondents who answered the smartphone brand other than the brand provided, is categorized under "Others". There are $3(0.8 \%)$ to the total respondents. Therefore, it is possible to say Huawei is the dominant and widely owned smartphone in Hawassa city followed by Samsung.

3. Do you have any intention to change your current brand of smart phone?

Table 3: Respondents Future Intention

\begin{tabular}{|l|l|l|l|l|l|}
\hline \multicolumn{2}{|c|}{} & Frequency & Percent & Valid Percent & Cumulative Percent \\
\hline \multirow{3}{*}{ Valid } & Yes & 192 & 53.9 & 53.9 & 53.9 \\
\cline { 2 - 6 } & No & 164 & 46.1 & 46.1 & 100.0 \\
\cline { 2 - 6 } & Total & 356 & 100.0 & 100.0 & \\
\hline
\end{tabular}

Source: Own Survey Questionnaire, 2017

As illustrated in table 3, $192(53.9 \%)$ of the respondents have the intention to change to other smartphone brands, and the remaining $164(46.1 \%)$ of respondents want to stay as loyal to their respective current smartphone brand. In addition to this, respondents were asked why they want to change to other smartphone brands. Most of the participants in the survey stated reasons behind their intention to change into other brands as low battery backup/ life, high copied nature of the brand, to enjoy good camera quality/ high megapixels, innovative features, RAM, internet connection, large screen size, a well-recognized brand that could show their lifestyle and other value-added features are stated. 
4. Which smart phone brand do you wish to change to?

Table 4: Respondents Future Intention to Change Current Smart Phone Brand to

\begin{tabular}{|l|l|l|l|l|l|}
\hline & & Frequency & Percent & Valid Percent & Cumulative Percent \\
\hline \multirow{5}{*}{} & Samsung & 47 & 23.4 & 23.4 & 23.4 \\
\cline { 2 - 6 } & Huawei & 6 & 3.0 & 3.0 & 26.4 \\
\cline { 2 - 6 } & Tecno & 65 & 32.3 & 32.3 & 58.7 \\
\cline { 2 - 6 } & LG & 2 & 1.0 & 1.0 & 59.7 \\
\cline { 2 - 6 } & Infinex & 8 & 4.0 & 4.0 & 63.7 \\
\cline { 2 - 6 } & Sony & 11 & 5.5 & 5.5 & 69.2 \\
\cline { 2 - 6 } & BlackBerry & 3 & 1.5 & 1.5 & 70.6 \\
\cline { 2 - 6 } & Asus & 2 & 27.9 & 1.0 & 71.6 \\
\cline { 2 - 6 } & iPhone & 56 & 0 & 27.9 & 99.5 \\
\cline { 2 - 6 } & HTC & 1 & 56.5 & 5 & 100.0 \\
\cline { 2 - 6 } & Others & 0 & & 100.0 & 100.0 \\
\cline { 2 - 6 } & Total & 201 & & & \\
\hline
\end{tabular}

Source: Own Survey Questionnaire, 2017

Table 4, shows that the preferred smartphone brands respondents intended to purchase in the future. Among the twelve brands shown and another brand, Tecno is the most preferred and desired brand which has the highest frequency of 65 from the total respondents with greater than 32.3\%. Apple iPhone is the second preferred brand, which has 56 frequency out of the total respondents and 27.9\%. The third is Samsung, which has 47 frequency of the total respondents is $23.4 \%$. The following are Sony, Infinex, and Huawei which each of them have 5.5\%, 4.0\%, and 3.0\% respectively. As we can see from the above figure, Blackberry, Asus, LG, and HTC are the least preferred brands by the respondents. From this, we can deduce that Tecno will be the dominant smartphone brand in the future followed by iPhone and Samsung.

\section{Smart Phone Product Features}

The feature can be defined as a touch screen feature, camera functionality, WiFi, High- resolution display, new design, waterproof and shockproof, LTE, or 4G speed internet connection. Besides that, smartphone features such as; application installation, high gigabytes of storage, large-screen and powerful processor. Respondents were asked to select smartphone features that can be considered as more important when they are involved in smartphone purchasing activity and they responded as depicted in figure 1 below.

Figure 1: Smart Phone Features

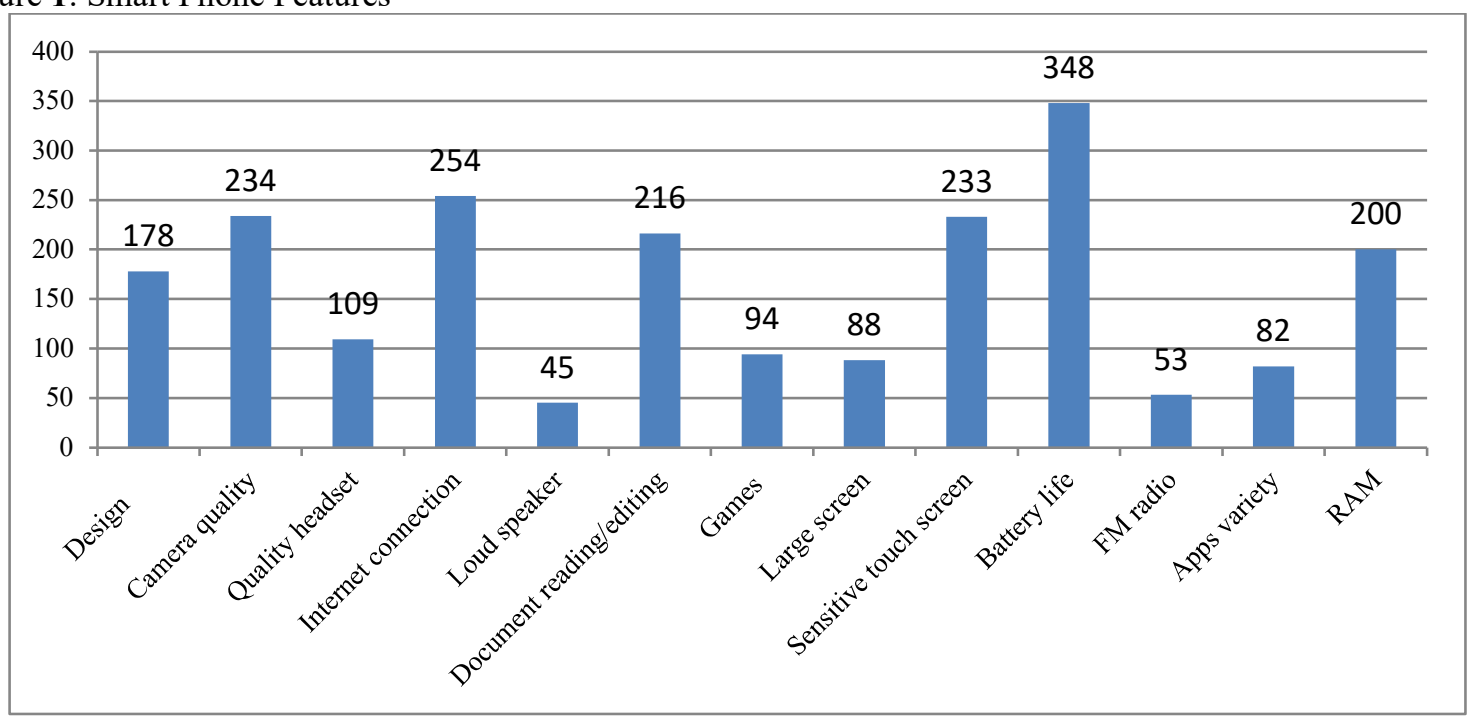

Source: Own Survey Questionnaire, 2017

As figure 1 shows, strong battery life was the most important feature preferred by the respondents while purchasing a smartphone. Now a day's smartphone manufacturers bring different models of smartphones to their brand name but still, the battery technology is not improved yet, as a result, consumers are eager to change currently possessed smartphones. As an example we can take Samsung, it is the world honored brand but characterized by weak battery life. Due to this reason, most Samsung users want to change to Tecno. Next to battery life; internet connection (254), camera quality (234), sensitive touch screen (233), and RAM (200) considered as the most important features. Other features like design (178), quality headset (109), game (94), large screen (88), and apps variety (82) are considered as moderately important features. The least preferred features are FM radio (53) and a 
loudspeaker (45). From this, we can say that not all smartphone features are equally considered or preferred when consumers purchase a smartphone.

\subsubsection{Results of Measures of Central Tendency and Dispersion}

Several factors affect consumers' purchase intention of smartphone brands. This part explains the descriptive statistics calculated based on the factors that affect the purchase intention of smartphone consumers in Hawassa city. The results for measures of central tendency and dispersion were obtained from 356 samples of respondents of actual smartphone consumers through a 5-point Likert scale are shown below.

Like Demis (2016), the researcher adopts an inherent assumption, which states that with the usage of any Likert scale that although the scale is truly ordinal, it is assumed to be on an interval scale with which statistical properties such as the mean can be justifiably used. Mean is the most common measure of central tendency and may be defined as the value which we get by dividing the total of the values of various given items in a series by the total number of items (Kothari, 2004). Accordingly, the researcher applied mean and standard deviation as the best measures for analysis based on the mean range developed by Al-Sayaad et al. (2006) cited in Demis (2013) of the following table:

Table 5: Five-Scaled Likert's Criterion

\begin{tabular}{|l|l|l|}
\hline No. & Mean Range & Response Options \\
\hline 1 & {$[1.00-1.80)$} & Strongly Disagree \\
\hline 2 & {$[1.80-2.60)$} & Disagree \\
\hline 3 & {$[2.60-3.40)$} & Neutral \\
\hline 4 & {$[3.40-4.20)$} & Agree \\
\hline 5 & {$[4.20-5.00]$} & Strongly Agree \\
\hline
\end{tabular}

Source: Al-Sayaad et al. (2006) cited in Demis, (2016)

Standard deviation is the most widely used measurement of variability or diversity used in statistics and probability theory. It shows how much variation or "dispersion" there is from the average mean, or expected value (Kothari, 2004). A low standard deviation indicates that the data points tend to be very close to the mean, whereas a high standard deviation indicates that the data are spread out over a large range of values. The minimum and maximum values are also considered to show the exact answers of the respondents of the questionnaire; because they are not all incorporated in that mean (average) value only. The sample mean is to show the majority of respondents as best predictors of the population and hence to infer for others (i.e., to the whole smartphone consumers in Hawassa city).

\subsubsection{Descriptive Statistics on Price}

In this sub-section, mean and standard deviation are applied for descriptive analysis.

Table 6: Descriptive Statistics on Price

\begin{tabular}{|l|l|l|l|}
\hline Item & $\mathrm{N}$ & Mean & SD \\
\hline Price is my main consideration when deciding whether to buy a smartphone & 356 & 4.0787 & .94615 \\
\hline I compare prices of other smartphone brands and store brands before I choose one & 356 & 4.0787 & .95209 \\
\hline I am willing to buy a smartphone even though the price is higher & 356 & 3.7697 & 1.09687 \\
\hline $\begin{array}{l}\text { The cheapness of some smartphone brands suggests to me that they may have some } \\
\text { risks, such as low quality }\end{array}$ & 356 & 3.9326 & .99347 \\
\hline I would be interested in discounts while purchasing the smartphone & 356 & 3.8146 & 1.03156 \\
\hline I look carefully to find the best value for money for smartphone brand & 356 & 3.7725 & 1.12909 \\
\hline Overall price & 356 & 3.9078 & .80589 \\
\hline Valid N (listwise) & 356 & & \\
\hline
\end{tabular}

Source: Own Survey Questionnaire, 2017

From the above table, out of the six individual scale items, the constructs "Price is my main consideration when deciding whether to buy a smartphone" and "I compare prices of other smart phone"s brands and store brands before I choose one" have the highest mean score of 4.0787 with a dispersion of .94615 and .95209 respectively. This mean value was categorized as a response scale of "strongly agree" (see Table 5). The minimum mean score of 3.7697 out of all was found for the question (sentence): "I am willing to buy a smartphone even though the price is higher". It has the equivalent 5-point Likert's response scale of "agree", with the dispersion value of 1.09687. The overall mean of the price is 3.9078 with the dispersion score of .80589 placed under the response option of "agree". Therefore, the price influences on the purchasing intention of the smartphone brand in Hawassa city.

\subsubsection{Descriptive Statistics on Product Feature}

Feature is an attribute of a product to meet the satisfaction level of consumers' needs and wants, through owning of the product, usage, and utilization of a product (Kotler et al., 2007). 
Table 7: Descriptive Statistics on Product Feature

\begin{tabular}{|l|l|l|c|}
\hline Item & $\mathrm{N}$ & Mean & SD \\
\hline $\begin{array}{l}\text { If two smartphones had the same features I would choose the smartphone that is the } \\
\text { current craze from an operating system point of view }\end{array}$ & 356 & 4.2500 & .83708 \\
\hline Battery life highly affects my smartphone purchasing decision & 356 & 4.2079 & .90479 \\
\hline $\begin{array}{l}\text { If a smartphone designer changes the user interface completely, I would welcome the } \\
\text { change of brand }\end{array}$ & 356 & 4.1264 & .93041 \\
\hline I would prefer new technology when purchasing a smartphone & 356 & 4.2135 & .84216 \\
\hline I would rather choose a smartphone brand that has fast and responsive & 356 & 4.3315 & .87996 \\
\hline $\begin{array}{l}\text { I would rather choose a smartphone brand that is known to integrate easily with all } \\
\text { PC operating system }\end{array}$ & 356 & 4.2837 & .86943 \\
\hline $\begin{array}{l}\text { I would rather choose a smartphone brand that is easy to use, thereby allowing me to } \\
\text { perform task faster }\end{array}$ & 356 & 4.3764 & .84846 \\
\hline The smartphone I have purchased includes all the important smartphone features & 356 & 4.2022 & .87764 \\
\hline Overall Product feature & 356 & 4.2489 & .66770 \\
\hline Valid N (listwise) & 356 & & \\
\hline
\end{tabular}

Source: Own Survey Questionnaire, 2017

As it is indicated in table 7 above, the mean and standard deviation for the product feature was calculated. The table shows that smartphone consumers are interested in a brand that is easy to use, thereby allowing them to perform tasks faster or makes their day to day life easier with a mean score of 4.3764 and a standard deviation of .84846 . Compared to other items the least mean score 4.1264 with $\mathrm{SD}=0.93041$ is calculated from the item entitled "If a smartphone designer changes the user interface completely, I would welcome the change of Brand" but still this means the score is placed under the "Agree" response category.

Moreover, the above table illustrated the overall mean and standard deviation of product feature i.e. mean score 4.2489 and 0.66770 standard deviation. This mean score is placed between the mean range of (4.20-500) and response category of "strongly agree". All consumers strongly agree with the items which state different smartphone features with maximum mean score range (4.20-500). From this, one can say that product feature is the major factor that can be accounted for smartphone purchase intention in Hawassa city.

\subsubsection{Descriptive Statistics on Brand Name}

According to the American Marketing Association (AMA), a brand is defined as the "name, term, symbol, or design, or a combination of them intended to identify the goods and services of one seller or group of sellers and to differentiate them from those of competition" (Kotler and Armstrong, 2006).

Table 8: Descriptive Statistics on Brand Name

\begin{tabular}{|l|l|l|l|}
\hline Item & $\mathrm{N}$ & Mean & SD \\
\hline I will consider the reputation of smartphone brand before purchasing & 356 & 3.7640 & 1.07229 \\
\hline Reliable and trusted brands are important to me when I purchase smartphones & 356 & 3.9438 & 1.08105 \\
\hline $\begin{array}{l}\text { I will make my purchase according to my favorite's smartphone brand, regardless of } \\
\text { the price }\end{array}$ & 356 & 3.4270 & 1.21389 \\
\hline I prefer to buy an international recognized smartphone brand & 356 & 3.9045 & 1.08349 \\
\hline Smartphone's brand name is my priority when making a purchase decision & 356 & 3.8708 & 1.12094 \\
\hline Overall Brand name & 356 & 3.7820 & .93514 \\
\hline Valid N (listwise) & 356 & & \\
\hline
\end{tabular}

Source: Own Survey Questionnaire, 2017

The result presented in Table 8 shows that consumers agree with the statement "Reliable and trusted brands are important to me when I purchase smartphones" with a greater mean score than other items (3.9438 mean and $1.08105 \mathrm{SD})$. We all know that brand name is not only used as differentiation rather a source of commitment to serve consumers in a manner that satisfies their demand. As we can see from table 8 again, consumers prefer to buy an international recognized smartphone brand (Mean 3.9045 \& SD 1.08349), they give priority to brand name when making a purchase decision (Mean $3.8708 \&$ SD 1.12094) and consider the reputation of the smartphone brand before purchasing (Mean3.7640 \& SD 1.07229).

The item entitled "I will make my purchase according to my favorite's smartphone brand, regardless of the price" recorded the least mean score (3.4270) and 1.21389 SD. The overall mean score of brand name (3.7820) is placed in the mean range of 3.40, 4.20 i.e. agree response category with SD of 0.93514 . Therefore, the smartphone brand name affects the purchasing intention of consumers in Hawassa city.

\subsubsection{Descriptive Statistics on Advertising}

Advertising consists of paid presentation and promotion ideas, products, programs, or services whether in magazines or newspapers, television, radio, billboards, bus card, direct mail, open days, events, exhibitions, speeches, or other mediums. Technological advancements have pushed institutions to do viral marketing through 
social networking sites like my space, twitter, and Facebook (Kashorda, 2002).

Table 9: Descriptive Statistics on Advertising

\begin{tabular}{|l|l|l|l|}
\hline Item & $\mathrm{N}$ & $\mathrm{Mean}$ & $\mathrm{SD}$ \\
\hline $\begin{array}{l}\text { I feel that exposure to ads has enhanced my involvement in purchasing } \\
\text { smartphone }\end{array}$ & 356 & 3.5365 & 1.18977 \\
\hline Advertising gives room for smartphone brand comparison & 356 & 3.6264 & 1.13251 \\
\hline $\begin{array}{l}\text { Due to ads exposure, my family members collectively decide } \\
\text { smartphones to be purchased }\end{array}$ & 356 & 3.1545 & 1.27213 \\
\hline $\begin{array}{l}\text { Advertising creates brand awareness and attracts me to choose } \\
\text { smartphone }\end{array}$ & 356 & 3.6461 & 1.02559 \\
\hline I feel good when I watch the ads of the smartphone I am already using & 356 & 3.7669 & 1.15995 \\
\hline Overall Advertising & 356 & 3.5461 & .96123 \\
\hline Valid N (listwise) & 356 & & \\
\hline
\end{tabular}

Source: Own Survey Questionnaire, 2017

As illustrated from table 9, the item entitled "Smartphone consumers feel better when they watch ads of smartphone brands they are currently using" scored high mean value compared to other items (Mean 3.7669 \& SD 1.15995). According to the criterion set under table 5, the mean value falls to the "agree level" of the respondents. While, the statement "Due to ads exposure, my family members collectively decide smartphones to be purchased" scored less mean value than other scales $(3.1545 \& \mathrm{SD}=1.27213)$ placed in the mean range of 2.60-3.40 neutral. As we can see from the above table the overall mean score of advertising is 3.5461 with $0.96123 \mathrm{SD}$, placed under the mean range of (3.40-4.20) means that most of the respondents agree on the role of advertising in motivating them to purchase a smartphone in Hawassa city.

\subsubsection{Descriptive Statistics on Social Influence}

Social influence means one person causes in another to make a change on his/her feelings, attitudes, thoughts and behavior, intentionally or unintentionally (Rashotte, 2007 cited in Kaushal and Rakesh, 2016).

Table 10: Descriptive Statistics on Social Influence

\begin{tabular}{|l|l|l|l|}
\hline Item & $\mathrm{N}$ & Mean & SD \\
\hline $\begin{array}{l}\text { I usually survey what others are buying and using regarding smartphone brands to } \\
\text { ensure that I make a right decision before I buy }\end{array}$ & 356 & 3.0365 & 1.22477 \\
\hline I trust my friends and family about their opinions and advices of smartphone & 356 & 3.1011 & 1.21997 \\
\hline My family \& friends influenced me a lot when I purchase a smartphone & 356 & 2.8652 & 1.21670 \\
\hline $\begin{array}{l}\text { I achieve a sense of belonging by purchasing the same smartphone that my friends } \\
\text { purchase }\end{array}$ & 356 & 2.8146 & 1.22390 \\
\hline I like to know what smartphone makes good impressions on my friends & 356 & 3.1461 & 1.22233 \\
\hline Salesperson's recommendation has impact on my smartphone purchasing decision & 356 & 3.1742 & 1.26179 \\
\hline Overall Social influence & 356 & 3.0229 & 1.01446 \\
\hline Valid N (listwise) & 356 & & \\
\hline
\end{tabular}

Source: Own Survey Questionnaire, 2017

As shown in Table 10 above, social influence consists of six items. From these factors, the item entitled "Salesperson's recommendation has an impact on my smartphone purchasing decision" scored superior mean score compared to other items 3.1742 mean score and 1.26179 SD. But according to the five-scaled mean criterion of Al-Sayaad et al. (2006), it has the response scale of "neutral", and the minimum mean score is 2.8146 with SD of 1.22390 recorded on the item of "I achieve a sense of belonging by purchasing the same smartphone that my friends purchase" also placed under "neutral" response scale.

Again from table 10, the aggregate mean value of social influence has become 3.0229. It has the response scale of "neutral" and its dispersion is 1.01446 from the mean. From this, one can say that social influence factors are not a major factor in determining the purchasing intention of consumers in Hawassa city.

\subsubsection{6.. Descriptive Statistics on Purchase Intention}

Purchase intention can also determine the possibility of a consumer's action leading to the actual purchase, and through identifying the intensity of purchase intention, there is a high possibility to purchase a certain product when the purchase intention is stronger (Dodds et al., 1991; Schiffman \& Kanuk, 2000). Moreover, purchase intention can also be treated as a metric for the prediction of consumer purchasing behavior (Bonnie et al., 2007). Besides that, the intention to purchase is known as consumers' tendency to behave towards an object; it is usually measured in terms of intention to buy (Kim \& Kim, 2004). Engel et al. (2001) proposed that purchase intention involves the subjective of future behavior. 
Table 11: Descriptive Statistics on Purchase Intention

\begin{tabular}{|l|l|l|l|}
\hline Item & $\mathrm{N}$ & Mean & SD \\
\hline I intend to purchase a smartphone based on my financial status & 356 & 4.1292 & .98447 \\
\hline I intend to purchase a smartphone that fulfills my usage requirement & 356 & 4.3455 & .88254 \\
\hline I prefer using my favorable smartphone brand regularly & 356 & 4.2584 & .82603 \\
\hline I intend to purchase a smartphone shown in ads & 356 & 3.4888 & 1.16638 \\
\hline I felt accepted by purchasing the same smartphone that others purchase & 356 & 2.8708 & 1.27606 \\
\hline Overall Behavioral intention & 356 & 3.8185 & .66578 \\
\hline Valid N (listwise) & 356 & & \\
\hline
\end{tabular}

Source: Own Survey Questionnaire, 2017

From the above table, out of the five individual scale items, the construct "I intend to purchase a smartphone that fulfills my usage requirement" has the highest mean score of 4.3455 with a dispersion of .88254 . This mean value was categorized as a response scale of "strongly agree" (see Table 5). The minimum mean score of 2.8708 out of all was found for the question (sentence): "I felt accepted by purchase the same smartphone that others purchase". It has the equivalent 5-point Likert's response scale of "neutral", with the dispersion value of 1.27606. The overall mean of purchase intention is 3.8185 with the dispersion score of .66578 . Generally, smartphone consumers in Hawassa city are willing to purchase a smartphone that fulfills their usage requirement, favorable brand, and displayed by different advertising medias' based on their financial performance.

\subsection{Inferential Statistics}

Inferential statistics are the statistical procedures that are used to reach conclusions about associations between variables. They differ from descriptive statistics in that they are explicitly designed to test hypotheses (Bhattacherjee, 2012). For this study, Karl Pearson's Correlation Coefficient and regression analyses were performed and conclusions are drawn concerning the sample, and decisions are made concerning the research hypothesis.

\subsubsection{Coefficient of Correlation Analysis}

Pearson Correlation Coefficient is a method that measures the strength of the linear relationship between two variables. It also indicates the direction, the strength, and the significance of the relationship among all variables. This coefficient assumes that there is a linear relationship between the two variables. Moreover, the two variables are causally related which means that one of the variables is independent and the other one is dependent; and a large number of independent causes are operating in both variables to produce a normal distribution (Kothari, 2004). The value of Pearson's correlation can fall between 0.00 and 1.00 . The value of 0.00 means there is no correlation whereas 1.00 means that is a perfect correlation. To know the strength and type of correlation between variables, the following table is set as a rule of thumb for discussion of this thesis.

Table 12: Rules of Thumb about Correlation Coefficients

\begin{tabular}{|l|l|}
\hline Coefficient Range & Strength of Association \\
\hline \pm .81 to \pm 1.00 & Very Strong \\
\hline \pm .61 to \pm .80 & High \\
\hline \pm .41 to \pm .60 & Moderate \\
\hline \pm .21 to \pm .40 & Weak \\
\hline \pm .00 to \pm .20 & None \\
\hline
\end{tabular}

Source: Bhattacherjee (2012) cited in Demis (2016) 
Table 13: Correlation between Variables

\begin{tabular}{|c|c|c|c|c|c|c|c|}
\hline \multicolumn{2}{|c|}{ Variables of the Study } & $\begin{array}{l}\text { Purchase } \\
\text { Intention }\end{array}$ & Price & $\begin{array}{l}\text { Product } \\
\text { Feature }\end{array}$ & $\begin{array}{l}\text { Brand } \\
\text { Name }\end{array}$ & Advertizing & $\begin{array}{l}\text { Social } \\
\text { Influence }\end{array}$ \\
\hline $\begin{array}{l}\text { Purchase } \\
\text { Intention }\end{array}$ & $\begin{array}{l}\text { Pearson Correlation } \\
\text { Sig. (2-tailed) } \\
\text { N }\end{array}$ & 1 & $\begin{array}{l}647^{* *} \\
.000 \\
356\end{array}$ & $\begin{array}{l}.662^{* *} \\
.000 \\
356\end{array}$ & $\begin{array}{l}.593^{* *} \\
.000 \\
356\end{array}$ & $\begin{array}{l}.561^{* *} \\
.000 \\
356\end{array}$ & $\begin{array}{l}.478^{* *} \\
.000 \\
356\end{array}$ \\
\hline Price & $\begin{array}{l}\text { Pearson Correlation } \\
\text { Sig. (2-tailed) } \\
\mathrm{N}\end{array}$ & & 1 & $\begin{array}{l}.664^{* *} \\
.000 \\
356 \\
\end{array}$ & $\begin{array}{l}450^{* *} \\
.000 \\
356 \\
\end{array}$ & $\begin{array}{l}404^{* *} \\
.000 \\
356\end{array}$ & $\begin{array}{l}302^{* *} \\
.000 \\
356 \\
\end{array}$ \\
\hline $\begin{array}{l}\text { Product } \\
\text { Feature }\end{array}$ & $\begin{array}{l}\text { Pearson Correlation } \\
\text { Sig. (2-tailed) } \\
\mathrm{N}\end{array}$ & & & 1 & $\begin{array}{l}.549^{* *} \\
.000 \\
356\end{array}$ & $\begin{array}{l}.483^{* *} \\
.000 \\
356\end{array}$ & $\begin{array}{l}.180^{* *} \\
.001 \\
356\end{array}$ \\
\hline Brand Name & \begin{tabular}{|l} 
Pearson Correlation \\
Sig. (2-tailed) \\
$\mathrm{N}$ \\
\end{tabular} & & & & 1 & $\begin{array}{l}.454^{* *} \\
.000 \\
356 \\
\end{array}$ & $\begin{array}{l}387^{* *} \\
.000 \\
356 \\
\end{array}$ \\
\hline Advertizing & $\begin{array}{l}\text { Pearson Correlation } \\
\text { Sig. (2-tailed) } \\
\mathrm{N}\end{array}$ & & & & & 1 & $\begin{array}{l}.344^{* *} \\
.000 \\
356 \\
\end{array}$ \\
\hline $\begin{array}{l}\text { Social } \\
\text { Influence }\end{array}$ & $\begin{array}{l}\text { Pearson Correlation } \\
\text { Sig. (2-tailed) } \\
\mathrm{N}\end{array}$ & & & & & & 1 \\
\hline
\end{tabular}

\section{Source: Own Survey Questionnaire, 2017}

As it is indicated in table 13 above, a significant positive relationship was found between each of the independent variables with the dependent variable. However, the strength of the relationship is different. The highest relationship was found between product features and purchase intention $(\mathrm{r}=.662, \mathrm{p}<.01)$. Moreover, the value of the correlation coefficient, which is .662, falls under the coefficient range of $( \pm .61$ to \pm .80$)$. This indicates that there is a high relationship between product features and purchase intention of smartphone consumers' in Hawassa city.

There is a significant relationship between price and purchase intention of smartphone consumers' in Hawassa city. This is because the p-value equal to 0.000 and less than the alpha value 0.05 . Moreover, the value of the correlation coefficient, which is .647 , falls under the coefficient range of ( \pm .61 to \pm .80 ). This indicates a high relationship between price and purchase intention of smartphone consumer's in Hawassa city.

Moreover, the table presents the association between the selected variables and purchasing intention for a sample of 356 smartphone consumers in Hawassa city. There is a moderate, however statistically significant relationship between brand name and purchase intention $(\mathrm{r}=.593, \mathrm{p}<.01)$. This would imply that the relationship between the brand name and consumers' smartphone purchase intention is high. The result in table 13 above further indicates that there is a substantial positive correlation between advertising and purchase intention $(\mathrm{r}=.561)$, which is statistically significant at a $99 \%$ confidence level. This indicates a moderate relationship between advertising and consumers' purchase intention in Hawassa city.

There exists a positive relationship between social influence and purchase intention of smartphone consumers in Hawassa city. This is because the p-value equal to 0.000 and less than the alpha value 0.05 . Moreover, the value of the correlation coefficient, which is .478 , falls under the coefficient range of ( \pm .41 to \pm .60 ). This indicates that there is a moderate relationship between social influence and purchase intention of smartphone consumers' in Hawassa city, but it is the least correlated factor compared to others.

\subsubsection{Regression Analysis of the Study}

To determine the extent to which the explanatory variables explain the variance in the explained variable, regression analysis was employed. Also with a regression analysis it can be determined whether the independent variables explain a significant variation in the dependent variable, including whether a relationship exists. The results of such analysis are narrated below. When there are two or more than two independent variables, the analysis concerning relationship is known as multiple correlations and the equation describing such relationship as the multiple regression equation (Kothari, 2004).

Before analyzing the data gathered by the schedule, the researcher has checked the necessary assumptions that have to fulfill to undertake analysis by multiple regression model. Four tests for CLRM assumptions namely normality, linearity, multicollinearity and independence of residual are conducted and discussed as follows:

Generally, the study discussed four major assumptions that must be fulfilled for one to analyze data using a multiple linear regression model. So, since all the four assumptions were not violated, the researcher examined the 
data collected by schedule using a multiple regression model as follows.

Table 14: Model Summary ${ }^{\mathrm{b}}$

\begin{tabular}{|l|l|l|l|l|}
\hline Model & R & R Square & Adjusted R Square & Std. Error of the Estimate \\
\hline 1 & $.806^{\mathrm{a}}$ & .650 & .645 & .39666 \\
\hline
\end{tabular}

Predictors: (Constant), Price, Product feature, Brand name, Advertising, Social influence

Purchase Intention

Source: Own Survey Questionnaire, 2017

Table 16 above displays the estimates of the multiple regression of behavioral intention against its variables for the sample of 356 consumers. "R" represents the value of the multiple correlation coefficients between the predictors and the outcome (Field, 2005 cited in Demis, 2016). Here, this "R" value represents the simple correlation between price, product feature, brand name, advertising, social influence, and purchase intention. Overall, they have a strong correlation.

Based on the results above, the value $\mathrm{R}$ square is 0.65 ; is the correlation between the dependent and independent variable values of the research. $\mathrm{R}^{2}$ is also called the squared multiple correlation coefficient or the coefficient of determination since $\mathrm{R}^{2}=(0.806) 2=.649636$, which rounds to .650 . Adjusted $\mathrm{R}^{2}(0.645)$ is taken for interpretation. It reflects that the total variation in the dependent variable (Purchase Intention) is explained or caused by $64.5 \%$ of the change (increase) in all independent variables (price, product feature, brand name, advertising, and social influence). The remaining $35.5 \%$ of the variation in overall smartphone consumers' purchase intention could be explained by other variables that are not incorporated under this study.

Finally, Std. error of the Estimate is a measure of the variability of multiple correlations. Therefore, as depicted in the model summary table above, the Std. error of the Estimate of this model is .39666. This indicates the variability of the multiple correlations is as much as this number.

Table 15: ANOVA (Analysis of Variance)

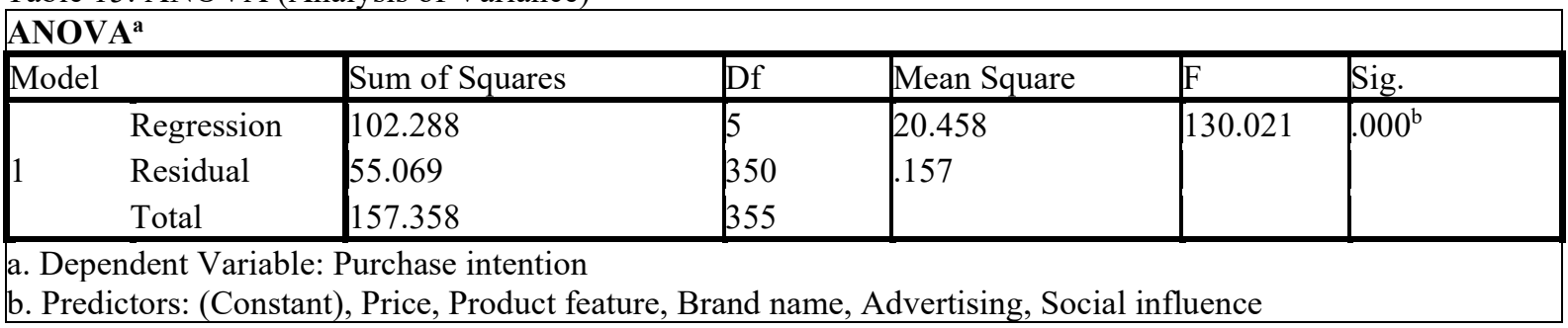

Source: Own Survey Questionnaire, 2017

Table 15 indicated that there is a statistically significant effect between the independent variables (price, product feature, brand name, advertising, and social influence) and dependent variable (Purchase intention) which the independent variable where $(F)$ value was $(130.021)$ at $(\alpha \geq 0.05)$ indication level, and, which states that there is a statistically significant effect of independent variables on purchase intention.

Table 16: Coefficients' Table on Multiple Regression of the Research Model

\begin{tabular}{|c|c|c|c|c|c|c|c|}
\hline \multicolumn{8}{|l|}{ Coefficients $^{\mathrm{a}}$} \\
\hline \multirow[t]{2}{*}{ Model } & \multicolumn{2}{|c|}{ Unstandardized Coefficients } & \multirow{2}{*}{$\begin{array}{l}\text { Standardized Coefficients } \\
\text { Beta }\end{array}$} & \multirow[t]{2}{*}{$\mathrm{T}$} & \multirow[t]{2}{*}{ Sig. } & \multicolumn{2}{|c|}{ Collinearity Statistics } \\
\hline & $\mathrm{B}$ & Std. Error & & & & Tolerance & VIF \\
\hline (Constant) & .500 & .141 & & 3.533 & .000 & & \\
\hline Price & .203 & .036 & .246 & 5.623 & .000 & .522 & 1.915 \\
\hline Product feature & .288 & .048 & .288 & 6.045 & .000 & .439 & 2.276 \\
\hline Brand name & .112 & .029 & 157 & 3.827 & .000 & .593 & 1.685 \\
\hline Advertizing & .118 & .027 & .171 & 4.447 & .000 & .676 & 1.479 \\
\hline Social influence & .152 & .024 & .232 & 6.437 & .000 & .772 & 1.296 \\
\hline
\end{tabular}

Dependent Variable: purchase intention

Source: Own Survey Questionnaire, 2017

Based on Table 18, the following equation is formed:

$\mathrm{Y}=0.500+0.246\left(\mathrm{X}_{1}\right)+0.288\left(\mathrm{X}_{2}\right)+0.157\left(\mathrm{X}_{3}\right)+0.171\left(\mathrm{X}_{4}\right)+0.232\left(\mathrm{X}_{5}\right)$

Where, $\mathrm{Y}=$ Purchase intention, $\mathrm{X}_{1}=$ Price $\mathrm{X}_{2}=$ Product feature, $\mathrm{X}_{3}=$ brand name, $\mathrm{X}_{4}=$ advertising, and $\mathrm{X}_{5}=$ Social influence

The individual effects of independent variables can be explained by their respective standardized beta coefficients. The $\mathrm{p}$ values of all the factors are well below 0.05 , which means that there is a significant relationship between the factors and the dependent variable. Based on the equation given above, the regression coefficient of the price is 0.203 . It indicates that the price of smartphones affects consumers' purchase intention positively.

The product feature has got a regression coefficient of 0.288 . It indicates that the feature of smartphones is 
positively affecting the purchasing intention. The regression coefficient of the brand name is 0.112 . It indicates that the brand name of the smartphone positively affects the purchasing intention of consumers. Besides, the regression coefficient of advertising is 0.118 . It signifies that advertising directed to smartphones affecting purchasing intention positively.

And finally, social influence has got a regression coefficient of 0.152. It indicates that the social influence of smartphones is positively related to purchasing intention. Among all variables, the product feature has got the highest beta of 0.288 . This means that it has got the strongest influence on purchasing intention as compared to other variables. Hence, a product feature is the highlighted predictor of purchasing intention, followed by price with beta 0.203 , social influence with beta 0.152 , advertising with beta 0.118 , and brand name at 0.112 .

\section{SUMMARY, CONCLUSIONS AND RECOMMENDATIONS}

\subsection{Summary of Major Findings}

The study aimed to assess the factors affecting consumers' purchase intention towards smartphones in Hawassa city. The total number of sample respondents for this survey was 356 . The collected data were analyzed using both descriptive and inferential statistics.

\subsubsection{Descriptive Analysis}

Based on the descriptive analysis in chapter 4, out of 356 respondents, there were $211(59.3 \%)$ males, and the remaining 145 (40.7) were female. While large numbers of the respondents fell between 18-28 years old that consists of 112 respondents and 101 respondents were between 29-38 years old. Through the analysis, most of the respondents (164) were Bachelor's Degree holders followed by Grade 8-12 (65). Concerning occupation, most of the respondents were government employees (143) followed by self-employed (98), student (87). While analysis of income per month showed that 105 respondents got 6200-8200 Ethiopian birr per month. Others; 98 (20004000), and 87 (4100-6100) got per month (see table 1).

According to the descriptive analysis of the study, variables discussed earlier under the dimension of price factor the statements entitled "Price is my main consideration when deciding whether to buy a smartphone" and "I compare prices of other smart phone's brands and store brands before I choose one" has scored highest mean value 4.0787. Even though the mean value is the same between two items different SD value is calculated. The overall mean value of the price is 3.9078. This implies that price influences consumers' smartphone purchases in Hawassa city.

Under product features, a smartphone brand that is easy to use, thereby allowing them to perform tasks faster has the highest mean value (4.3764). However, the least the mean value for the willingness of consumers to adopt changes in user interface was found with mean values of 4.1264. Even though the score was minimum compared to other items, the mean value is placed under the agree response category. The overall mean score of the product feature was 4.2489. This implies that product feature is a major motive to consumers purchasing of smartphone brands.

Out of the five items of Brand name, reliable and trusted brands have a positive influence on consumers' purchase intention towards smartphones has scored the highest mean value of 3.9438. But the item entitled "I will make my purchase according to my smartphone brand, regardless of the price" scored the least mean value of 3.4270 respectively. The overall mean of the brand name dimension is also 3.7820 . This implies that brand name influences the purchase and use of smartphones in Hawassa city.

The other independent variable, advertising (Ad) influences the intention to perform a behavior. Among the five scale items of advertising, the one with the highest mean value of 3.7669 consumers feels good when they watch the ads of the smartphone they are currently using. The other item with a minimum mean score of 3.1545 is "Due to ads exposure, my family members collectively decide smartphones be purchased". The overall mean value of advertising is 3.5461. This mean score is placed under the agree response category (see table 5). From this one can say that advertising has a role in motivating respondents to perform the purchase action toward a given smartphone brand in Hawassa city.

Social influence was also another independent variable considered in the study. Out of six items, five items are found in the mean range of (2.60-3.40) i.e., neutral response category. The same is true when we see the result of the overall mean value of social influence 3.0229. This implies that social influence is not a major factor when consumers decide to purchase a smartphone in Hawassa city.

Under purchasing intention, a smartphone that fulfills their usage requirement influences consumers' intention to buy a smartphone. It has the highest mean value of 4.3455 as when we compared with other scale items of purchase intention. The item entitled "I felt accepted by purchasing the same smartphone that others purchase" has the least mean value of 2.8708 of all purchase intention scale items (see table 11). The overall mean value of purchase intention is 3.8185 . This also implies that consumers are willing to buy smart a phone that fulfills their usage requirement, favorable in brand aspect, and which matches their financial status.

\subsubsection{Inferential Analysis}

In Pearson Correlation analysis, product feature has the highest correlated factor with purchase intention $(0.662)$ 
and found highly significant at the 0.01 level $(\mathrm{p}<0.01)$ among the five independent variables. The next highest correlation $(0.647)$ is seen between purchase intention and price. According to the regression model summary, adjusted $\mathrm{R} 2=.645$ means that the total variance in the purchase intention is caused by $64.5 \%$ of the change in all independent variables (price, product feature, brand name, advertising, and social influence). So, there is a significant relationship between purchase intention and all independent variables. Smartphone manufacturers and marketers should consider those factors when they are in production as well as in the marketing of their smartphone brand.

\subsection{Conclusion}

The objective of this thesis was to assess factors affecting consumers' purchase intention of smartphones in Hawassa city. Based on the objective of the study, the following conclusions were drawn from the above findings and summary of the study.

The majority of the respondents surveyed were having owned Huawei smartphones followed by Samsung. Moreover, most of the respondents have an intention to change their current smartphone brand to Tecno due to long battery life as compared to others.

The SPSS Pearson's correlation result illustrated that product features (.662) and price (.647) are leading factors influencing the purchasing intention of smartphones, as first and second respectively. The variables mentioned here above have a highly significant relationship at 0.01 levels of significance.

The other analysis finding relies on the regression output of adjusted $\mathrm{R} 2=.64 .5 \mathrm{implies}$ that all independent variables (price, product feature, brand name, social influence, and advertising) along make a case for the full variance of purchase intention by 64.5 percent. The results of this study shows that product features, price, brand name, social influence, and advertising have an effect on customers purchase intention towards smartphones. Overall, the researcher found that there's a powerful relationship between the dependent and independent variables.

\subsection{Recommendation}

In this ever-growing competitive smartphone market, understanding consumer's behavior, and take care of their satisfaction is the secret of being competitive and successful in the market. This study will provide some significant knowledge and information to the smartphone manufacturers as well as marketers to uncover consumers' intentions to anticipate consumers buying behavior and surmount the smartphone market in Hawassa city.

In this study, five independent variables were identified that affect consumers' purchase intention of smartphones in Hawassa city. However, not necessarily all the variables influence consumers to the same extent. Based on the research findings the following recommendations are forwarded:

The result of the descriptive and inferential analysis shows that the majority of smartphone consumers put product features first as a motivator to purchase a smartphone brand.

Therefore;

$\checkmark$ Product features are significantly important to consumers when making their purchasing decision. Thus smartphone firms ought to perform a periodic survey to assist in distinctive extra options and judge which of them to feature to its products. In this manner, each smartphone manufacturing company can assess every product feature's value to consumers versus its cost to the company. Moreover, by determining which combination of these features match the current trends and consumer needs would be cost-effective to smartphone companies.

$\checkmark$ Now a day's technology of smartphones becomes more innovative but their battery life is still under the question mark. Most of the respondents in the survey responded that longer battery life is the primary reason to change the current brand of their smartphone to Tecno Mobile and considered this feature first. Therefore, smartphone manufacturers should improve battery life just like other features.

$\checkmark$ Price is the second factor that affects the intentions of smartphone consumers in Hawassa city. Thus, it is advisable for smartphone manufacturers and marketers to follow a value-based pricing strategy. This means that consumers should get the benefit that matches with what they give up. The price of a smartphone is so important to the consumers and it is the second variable to be considered. If a smartphone manufacturer could provide a smartphone with a very good product feature, consumers will buy it, if they perceive it as the feature matches with the price.

$\checkmark$ The third factor that affects smartphone purchase intention is social influence. The research finding indicates that social influence has a significant impact on smartphone consumers' purchasing intention, where consumers are referring to friends, family, colleagues, professionals, and sales personnel. Therefore, manufacturers and marketers of smartphones should strive to create positive word of mouth among consumers.

$\checkmark$ Based on the research result advertising is ranked as the fourth factor that affects smartphone consumers when they want to purchase. Smartphone companies should advertise their products to create awareness, to persuade, to remind consumers that the product still exists. It will therefore be recommended to the producers of a 
smartphone that, the advertising messages should be designed in a manner that is clear, understandable, and not offensive to the consumers.

$\checkmark \quad$ The other important finding of this study is that brand name has a relatively low effect on the intention to buy smartphone brands compared to other selected variables examined in the study. But, this does not mean that smartphone providers shouldn't focus much on branding strategy rather it is a source of competitive advantage.

$\checkmark \quad$ In a highly competitive market, the brand name of a product becomes one of the most imperative factors in gaining competitive advantage among competitors. Thus, the smartphone manufacturers need to build their strong brand name, establish the link of their brand name with the consumers through different sources of communication.

\section{References}

Al-Sayaad, J., Rabea, A., Samrah, A. (2006). Statistics for Economics and Administration Studies. Dar Hafez, Jeddah, Kingdom of Saudi Arabia.

Amit, S., \& Ajay, C. (2015). Consumer buying preference towards entry level smart phone. International Journal of Applied Business and Economic Research, Vol: 13(3), PP. 1173-1189.

Amrit, M. (2014). Consumer behavior towards smart phone industry in Indian market (Master's thesis). Dublin Business School, India. Available Online at http://esource.dbs.ie/bitstream/ handle /10788/1812/mba_mohan_a_2014.pdf?sequence=1.

Ayodele, Adeola, A., \& Chioma, D. I. (2016). Factors influencing smart phone purchase behavior among young adults in Nigeria. International Journal of Recent Scientific Research, Vol: 7, (9), pp. 13248-13254. Available Online at http://www.recentscientific.com.

Bhattacherjee, A. (2012). Social Science Research: Principles, Methods, and Practices. University of South Florida: Scholar Commons.

Chew, J. Q., Lee, J. H., Lim, C. T., Loke, W. W., \& Wong, T. K. (2012). Exploring the factors affecting purchase intention of Smartphone (Bachelor's thesis). University Tunku Abdul Rahman, Perak Campus, Malaysia. Available online at http://eprints.utar.edu.my/697/1/MK-2012-1004230.pdf.

Cochran, W. G. (1977). Sampling Techniques (3rd ed.). New York: John Wiley \& Sons.

Creswell, J. W. (2003). Research Design: Qualitative, Quantitative, and Mixed Method Approaches (2 ${ }^{\text {nd }}$ ed.). California: Sage Publications.

Demis, A. (2016). Assessment of consumers' buying Behavior towards nonlife insurance products of Africa Insurance Company (S.C), Hawassa branch (Master's thesis). Hawassa University, Ethiopia.

Dodds, W. B., Monroe, K. B., \& Grewal, D. (1991). Effects of price, brand, and store information on buyers' product evaluations. Journal of Marketing Research, Vol: 6, pp. 307-319.

Gupta, R., \& Sheoran, B. (2013),Consumer Behavior on Smartphone's - A Study on The Perceptions of Youth Population While Purchasing Smart phone's, International Journal of Research in Management \& Social Science, Vol: 1(1), pp. 61-73.

Kashorda, M. (2002). Using information technology in higher education: Age publishers.

Kaushal, S. K. \& Rakesh, K. (2016). Factors affecting the purchase intension of smart phone: A study of young consumers in the city of Lucknow. Pacific Business Review International, Vol: 8 (12).

Kaushal, S. K. \& Rakesh, K. (2015). Consumers' reaction towards smart phones: A study of students of university of Lucknow, India. Journal of Management Research, Vol: 7(2).

Keller, K. (1998). Strategic Brand Management (1 ${ }^{\text {st }}$ ed.).Upper Saddle River: Prentice Hall

Kothari, C., R. (2004). Research Methodology: Methods and Techniques (2nd Revised Ed.). India: New Age International Publishers.

Kotler, P., \& Armstrong, G. (2006). Principles of marketing (1 $11^{\text {th }}$ ed.). Upper Saddle River, NJ: Pearson Education, Inc.

Lim, P. L., Poon, K. L., Tee, C. F., Thamil, S. A/L P. (2014). Factors affecting purchase intention towards smart phone brand: A study of young female adult consumers (Bachelor's thesis). Universiti Tunku Abdul Rahman, Malaysia.

Liu, C.M. (2002). The effects of promotional activities on brand decision in the cellular telephone industry. The Journal of Product \& Brand Management, Vol:11 (1), pp. 42-51.

Mesay, S. (2013). Factor affecting consumer buying behavior of mobile phone devices. Mediterranean Journal of Social Science, Rome -Italy, Vo: 14 (12), pp. 103-112.

Nagarkoti, B. (2009). Factors influencing consumer behavior of Smartphone users (Bachlor's thesis). Helsinki: Arcada Publishers. Available online at http://theseus32-kk.lib.helsinki.fi /bitstream /handle/10024/70466/Nagarkoti_Bishal.pdf?sequence=1.

Rashotte, L. (2007). Social Influences affecting buyer behavior. Retrieved from http:// www. Blackwellpublishing.com443 /sociologist/docs/BEOSS1413.pdf. 
Sabnam, S. (2016). Influencing factors on consumer buying behavior of smart phones (Bachelor's Thesis). Turku University of Applied Sciences, Nepal. Retrieved from http:/www. pbr.co.in/June2016/1.pdf.

Schiffman, L. G., \& Kanuk, L. L. (2000). Consumer Behavior (7th ed.). Wisconsin: Prentice Hall.

Surendra, M., Manminder, S. S., \& Avijeet, S. T. (2013). A study on the factors influencing consumer's purchase decision towards smart phones in Indore. International Journal of Advance Research in Computer Science and Management Studies, Vol: 1(6), pp. 14-20.

Tanzila, Ali, A. S., \& Nazish, T. (2015). Buying behavior of smart phone among university students in Pakistan. International Journal of Business \& Management, Vol: 3(1), pp. 2321-8916.

Wang, X. (2012). Attitude toward the Advertising and Subjective Norm on Purchase Intention: A Case of Television Advertising of Beauty and Personal Care Products in Bangkok. Doctoral dissertation. University of the Thai Chamber of Commerce. 